\title{
Ke čtvrtstoletí vzniku kateder primární pedagogiky: Reflexe proměn vzdělávání učitelů primárních škol po roce 1989
}

\author{
Vladimíra SPILKová
}

Analytická zpráva reflektující třicetiletý vývoj vzdělávání učitelů primárních škol na českých pedagogických fakultách vznikla na základě žádosti o podrobnější zpracování plenárního referátu, který byl přednesen na mezinárodní konferenci $v$ Liberci 18.-19. ř́jina 2018 (Spilková, 2019). Tato konference byla věnována 25 . výročí vzniku kateder primární pedagogiky v České republice. Tento text chápu jako svůj príspěvek $\mathrm{k}$ oslavám čtvrtstoletí pracovišt, které sehrály významnou roli v transformaci vzdělávání učitelů (nejen) primárních škol a v proměnách pojetí pedagogiky (nejen primární). ${ }^{1}$

Transformaci vzdělávání učitelů je třeba reflektovat $\mathrm{v}$ širším kontextu společenských a politických proměn v České republice po roce 1989, a to zejména ve vztahu ke školské reformě, koncepčním východiskům proměn vzdělávání a $k$ vzdělávací politice v oblasti učitelské profese, př́pravného vzdělávání učitelů i jejich dalšího profesního rozvoje (Spilková \& Hejlová, 1999, 2010).
Retrospektivní pohled na daný fenomén umožnil vymezit čtyři vývojové mezníky: 1. první polovina devadesátých let 20. století, 2 . druhá polovina devadesátých let 20. století, 3. první desetiletí 21 . století, 4. druhé desetiletí 21 . století.

\section{Prviní Polovina DeVadesátÝch}

\section{LET 20. STOLETÍ}

Z hlediska kontextuálních faktorů byla nejzávažnějším problémem absence vzdělávací politiky týkající se vzdělávání učitelů. $\mathrm{O}$ zásadním podcenění role učitele v transformujícím se školském systému vypovídá skutečnost, že MŠMT neprezentovalo až do roku 1995 žádnou představu o tom, jak by mělo vypadat prrípravné a další vzdělávání učitelů. Neexistenci koncepčního materiálu alespoň rámcově vymezujícího systém př́ípravy učitelů v České republice považovala za závažný problém také Akreditační komise, která v letech 1993-1995 prováděla akreditaci

\footnotetext{
${ }^{1}$ Text si dovoluji věnovat památce prof. Jiř́iho Kotáska a prof. Zdeňka Heluse, prvním porevolučním děkanům Pedagogické fakulty Univerzity Karlovy v Praze a klíčovým aktérům založení katedry primární pedagogiky na této fakultě, kterou jsem měla čest více než dvacet let vést.
} 
pedagogických fakult (Kurzweil, Mikulec \& Vinš, 1995).

Absence vzdělávací politiky $\mathrm{v}$ kombinaci $s$ autonomií vysokých škol přispěla $\mathrm{k}$ tomu, že se vytvořil prostor pro reformu „zdola“, príležitost hledat a ověřovat inovace $\mathrm{v}$ př́ípravě učitelů. Přes mnohá pozitiva však tyto „svépomocné" reformní aktivity bez společného koncepčního rámce a v mnoha ohledech živelný vývoj přinesly řadu negativních změn. $V$ souvislosti $\mathrm{s}$ postavením pedagogických fakult $\mathrm{v}$ rámci univerzit vedla liberální politika státu k podceňování významu kvalitní př́pravy budoucích učitelů, $\mathrm{k}$ chronickému podfinancování a postupně i personálnímu „tunelování" těchto fakult v rámci některých univerzit. Proces postupného odsávání kapacit, rušení či přesuny pracovišt na nově vznikající fakulty vedl na některých pedagogických fakultách $\mathrm{k}$ proměně $\mathrm{v}$ jakési „zbytkové" fakulty hraničící s ohrožením jejich další existence (Urbánek, 2013; Spilková, 2016). Většina negativních důsledků tohoto vývoje se projevila zejména $\mathrm{v}$ pojetí vzdělávání učitelů pro 2 . stupeň základní školy a školy střední. Na mnoha univerzitních fakultách se objevil tlak na de-profesionalizaci vzdělávání této kategorie učitelů, který vyústil ve výrazné omezení jeho teoretické i praktické profesní složky.

V oblasti učitelství pro primární školu byla zcela odlišná situace. Idea profesionalizace byla od počátku transformačního úsilí naopak považována za klíčové koncepční východisko ke změnám $\mathrm{v}$ př́ípravě této kategorie učitelů na všech pedagogických fakultách (byt's různou mírou důrazu na profesionalizaci i $s$ rozmani- tostí cest $\mathrm{k}$ její realizaci). Charakteristickým rysem tohoto období byla intenzivní spolupráce všech českých pedagogických fakult a do poloviny devadesátých let i slovenských fakult, resp. pedagogických pracovišt', které měly roli garanta koncepce učitelství pro primární školu. Vưdčí roli $\mathrm{v}$ transformaci a $\mathrm{v}$ iniciaci spolupráce ve výzkumu i při sdílení zkušeností z procesu inovací studia hrály fakulty v Praze, Brně, Ostravě a Olomouci. Hodnota a význam intenzivní spolupráce od roku 1991, jejímž výsledkem bylo poměrně rychlé nalezení shody v základních koncepčních východiscích žádoucích proměn, vynikne při srovnání se situací v př́pravě učitelů pro sekundární školy.

Dalším charakteristickým rysem tohoto období bylo, že hlavní protagonisté změn $\mathrm{v}$ př́ípravě učitelů pro primární školu na pedagogických fakultách (H. Lukášová-Kantorková, V. Spilková, A. Nelešovská, H. Horká, E. Lukavská, L. Prokešová, V. Václavík a řada dalších) se současně velmi výrazně angažovali $\mathrm{v}$ transformaci školství, zejména $\mathrm{v}$ proměnách primárního vzdělávání. At už to bylo v rámci nejrůznějších profesních asociací (zejm. NEMES, PAU), nebo $\mathrm{v}$ rámci inovativních a alternativních projektů (např. waldorfská a Montessori pedagogika, Zdravá škola, Začít spolu / Step by step, RWCT, dramatická výchova).

Významná role a angažovanost klíčových osobností z pedagogických fakult $\mathrm{v}$ procesu transformace primárního vzdělávání přispěla ke shodě napříc profesní komunitou $\mathrm{v}$ názorech na žádoucí proměnu primárního vzdělávání a primární školy. 
Sdíleným vůdčím konceptem se stalo humanistické pojetí primárního vzdělávání jako na dítě orientovaného, osobnostně rozvíjejícího pojetí, chápání primární školy jako služby dítěti, pomoci $\mathrm{v}$ jeho individuálním i sociálním rozvoji, jako místa, kde jsou vytvářeny prŕležitosti $\mathrm{k}$ celistvé a všestranné kultivaci dětské osobnosti a k rozvíjení potencialit, které v každém dítěti jsou (Helus, 1991, 2004; Lukášová, 2003; Spilková, 1991, 1997).

Vůdčí osobnosti v oblasti transformace primárního vzdělávání po roce 1989 podnítily diskusi o změně paradigmatu. Vytvořily a postupně propracovaly nový koncept primárního vzdělávání. Zdůvodnily potřebné změny v pojetí cílů $\mathrm{v}$ intencích holisticky chápané kultivace dětské osobnosti, snahu překonat jednostranné materiocentrické pojetí vzdělávání a obsah výuky koncipovat více $\mathrm{v}$ souladu s potřebami a vývojovými možnostmi dětí mladšího školního věku. $V$ souladu $s$ proměnami v pojetí cílů a koncipování obsahu primárního vzdělávání byly elaborovány také klíčové principy kvalitních procesů učení v podobě charakteristických rysů nové didaktické koncepce výuky, kultury učení. Důraz byl položen na vzájemně respektující komunikaci mezi učitelem a žáky a žáky navzájem a mezi učitelem a rodiči, dále na bezpečné a podnětné prostředí pro učení, na konstruktivistické přístupy, kooperativní učení a na kvalitativní, formativní hodnocení.

V tomto období došlo ke konstituování primární pedagogiky jako svébytného, výrazně antropologicky orientovaného oboru, který se kriticky vymezil vůči tra- diční tzv. bezdětné pedagogice. Primární pedagogika se přihlásila $\mathrm{k}$ principům humanistické psychologie, slovy Z. Heluse $\mathrm{k}$ „pedocentrismu nové generace“, jako základnímu východisku pro směřování školního vzdělávání z hlediska hodnot. Rychlý rozvoj primární pedagogiky jako specifické autonomní vědní oblasti se stal základem pro vznik samostatných kateder primární pedagogiky (jako první vznikla katedra v Liberci v roce 1993, v Praze pak v roce 1994).

Poměrně rychle nalezená shoda na pojetí primárního vzdělávání, rozvoj primární pedagogiky, postupný vznik samostatných kateder, které tím získávaly roli garanta celkové koncepce studia, vytvořily př́znivé podmínky pro rychlé nastartování potřebných změn. Od roku 1992 začalo pracovat neformální sdružení - grémium pedagogických fakult, resp. pracovišst a osobností, které garantovaly učitelství pro primární vzdělávání. Vůdčí roli v grémiu hrály v této době fakulty v Praze, Brně, Ostravě a Olomouci. Byla společně formulována základní filozofie prŕpravy této kategorie učitelů. Její vůdčí principy byly odvozeny z osobnostně rozvíjejícího, na dítě orientovaného pojetí primárního vzdělávání, které implikuje změnu $\mathrm{v}$ hierarchii rolí a klíčových profesních kompetencí učitele dětí daného věku.

Z hlediska rolí dominuje pojetí učitele jako facilitátora osobnostně-sociálního rozvoje žáka, průvodce na vzdělávací cestě, který vytvárí kvalitní vzdělávací situace a podmínky pro úspěšné učení u všech žáků, jako citlivého diagnostika v odhalování individuálních možností a vzděláva- 
cích potřeb žáků, který se snaží dotáhnout každého žáka $\mathrm{k}$ jeho osobnímu maximu. Ve vazbě na uvedené pojetí rolí učitele se u této kategorie učitelů zásadně mění i hierarchie profesních kompetencí z hlediska jejich významu pro kvalitní vykonávání profese. Důraz je kladen na kompetenci pedagogickou a psychodidaktickou, tedy na způsobilost zprostředkovávat základy oborů, obsah učiva v nejširším slova smyslu (znalosti, dovednosti, postoje, hodnoty) s ohledem na věkové a individuální možnosti žáků, vytvářet bezpečné a podnětné prostředí pro učení s důrazem na vnitřní motivaci k učení, činnostní metody, spolupráci mezi žáky a kvalitní zpětnou vazbu.

Kromě kompetence sociální, komunikativní a diagnostické je nově (pro české školství netradičně) zdůrazňován význam kompetence $\mathrm{k}$ reflexi a sebereflexi, $\mathrm{k}$ systematickému rozvoji profesní identity, $\mathrm{k}$ sebepojetí $\mathrm{v}$ roli učitele, ke kultivaci vlastního pojetí výuky. Oborová kompetence ztrácí svou dosavadní dominantní roli. Předmětem diskusí se stává specifická multidisciplinární oborová kompetence charakterizovaná mnohostranností jazykového, literárního, vlastivědného, matematicko-prrírodovědného a múzického vzdělání zahrnujíćího i tělesnou kulturu. Obsahová šiře oborové kompetence vede $\mathrm{k}$ úvahám o integrativních př́stupech, hledání styčných bodů mezi různými obory.

Konsenzuálně přijatý princip profesionalizace jako východiska $k$ proměně pregraduální přípravy byl východiskem ke snaze změnit proporce mezi jednotlivými dimenzemi stávajících studijních programů. To znamenalo přenést těžiště studia od dosud dominantní oborové/předmětové složky př́pravy $\mathrm{k}$ pedagogicko-psychologické, oborově-didaktické a osobnostně-kultivační složce studia. Navrhovaná změna v obsahových akcentech představovala $\mathrm{v}$ kontextu vývoje $\mathrm{v}$ posledních desetiletích radikální zásah - po celou dobu existence tohoto vysokoškolského oboru dominovalo Chlupovo pojetí vzdělávání učitelů $s$ důrazem na oborovou/předmětovou př́pravu. Nyní se měl stát východiskem koncept Př́íhodův s pojetím učitele jako odborníka, experta v pedagogicko-psychologických oborech a tomu odpovídající přípravy na učitelskou profesi.

Idea profesionalizace jako klíčové východisko ke koncepci vzdělávání budoucích učitelů primární školy mělo zásadní význam nejen pro nový model studia, ale bylo důležité pro argumentaci při obhajování univerzitního magisterského vzdělávání pro tuto kategorii učitelů. Od roku 1990 došlo několikrát $\mathrm{k}$ jeho zpochybnění, nejzávažněji v roce 1995, kdy MŠMT vytvořilo dokument Učitel s návrhem koncepce př́ípravného a dalšího vzdělávání učitelů. V tomto materiálu je navrhováno pro učitele primárního vzdělávání neuniverzitní bakalářské studium. Vůdčí osobnosti primární pedagogiky společně zformulovaly a publikovaly argumenty na obhajobu plnohodnotného univerzitního studia. Výrazná profesionalizace vzdělávání učitelů primární školy se stala vůdčím argumentem, nebot' $\mathrm{v}$ důrazu na pedagogickou a psychodidaktickou prípravu je nesporně (na rozdíl od oborové složky př́pravy) legitimován požadavek na univerzitní vzdělání. 
Kromě změny v obsahových dominantách studijních programů byly $\mathrm{v}$ tomto období dalšími deklarovanými principy proměny: a) integrace studia (jak uvnitř pedagogických oborů, tak mezi pedagogikou a psychologií, oborem a oborovou didaktikou, obecnou didaktikou a oborovými didaktikami, teoretickým studiem a praxí) s tím, že základem pro integraci do smysluplného celku, páteří studia by se měl stát nový obor primární pedagogika; b) osobnostní rozvoj studenta, personalistické pojetí přípravy; c) posílení praxe, změna jejího pojetí, gradující systém praxí po celou dobu studia $s$ důrazem na vlastní vyučovací činnost a její reflexi namísto hospitací; d) změny v metodách výuky (činnostní, zkušenostní, prožitkové, kooperativní formy učení); e) individualizace studia, osobní profilace, specializace aj.

Sdílená koncepční východiska a principy proměny vzdělávání učitelů primárních škol byly základem reformního úsilí na jednotlivých pedagogických fakultách. Vètšina pokusů o změnu studijních programů však narážela na nečekaně velké překážky. Jednou z příčin byla setrvačnost a rigidita $v$ názorech na pojetí učitelského vzdělávání, parciální zájmy kateder, zúžený úhel pohledu skrze vlastní obor, boje o výukové hodiny apod. Jako jeden z největších problémů realizace reformních projektů studia se ukázal způsob rrízení tohoto oboru, zejména nevyjasněné kompetence mezi vedením fakulty, katedrami a dalšími zainteresovanými aktéry.

Poměrně brzy se ukázalo (zhruba v letech 1991-1993), že za stávajících podmínek v podstatě nelze oficiální cestou a ve větším měřítku výraznější změny prosadit. To byl impulz ke vzniku několika alternativních studijních programů, které však měly omezenou působnost. Nejvýraznější alternativy studia učitelství pro primární školu byly vytvořeny na pedagogických fakultách v Ostravě a Praze (Ries, Kantorková et al., 1994; Spilková, 1994; Štech et al., 1995).

Také na dalších pedagogických fakultách lze sledovat snahu prosadit sdílené principy transformace do praxe prípravy učitelů. $S$ odvoláním na závěry akreditace pedagogických fakult - „ve výuce učitelství pro 1 . stupeň ZŠ existují výrazné inovační snahy“ (Kurzweil et al., 1995) a „výrazné snahy inovovat výuku učitelů 1 . stupně ZŠ jsou patrné na všech navštívených fakultách“ (Mareš \& Beran, 1995) - lze konstatovat, že první polovina devadesátých let byla dobou výrazného reformního kvasu, at́ už v podobě ucelenějších pokusů, či dílčích změn.

\section{DruHÁ POLOVINA DEVADESÁTÝCH LET 20. STOLETÍ}

V tomto období výrazně poklesla intenzita mezifakultní spolupráce $\mathrm{v}$ transformačním úsilí, nebot v centru pozornosti bylo zavádění inovací a řešení specifických problémů v kontextu vlastní fakulty a univerzity. V teoretické rovině byla hlouběji propracována koncepční východiska proměny formulovaná v první polovině devadesátých let. Jednalo se zejména o reflektivní model vzdělávání učitelů, personalistickou koncepci, konstruktivistické př́stupy, rozvoj profesní identity a sebepojetí v roli učitele, 
utváření pojetí výuky u studentů učitelství, kompetenční pojetí, jádrové hodnoty učitelské profese apod.

Za jedno z nejvýznamnějších pozitiv vývoje ve druhé polovině devadesátých let lze považovat další rozvoj oboru primární pedagogika do podoby ucelenějšího systému poznání, který s oporou o teoretické, historické, komparativní, empirické a experimentální přístupy řeší otázky vzdělávání a kultivace dětí mladšího školního věku s ohledem na věková specifika i jejich individuální možnosti a potřeby. Významnou roli $\mathrm{v}$ rozvoji oboru hrála také možnost specializovat se $\mathrm{v}$ rámci doktorského studia na problematiku primární pedagogiky (v Praze, Olomouci, Brně).

Rozvoj primární pedagogiky byl výrazně podpořen vznikem samostatných kateder, které se systematicky zaměřily na teorii, výzkum i podporu praxe v této oblasti. První katedry primární pedagogiky byly založeny v Liberci, Olomouci, Praze, Ostravě a Hradci Králové. Institucionální zajištění oboru mělo zásadní význam pro prosazování koncepčních změn $\mathrm{v}$ učitelském studiu. Katedry primární pedagogiky se postupně stávaly profilovými katedrami s kompetencí vytváret koncepci studia a garantovat její realizaci. Ve vztahu $\mathrm{k}$ ostatním katedrám participujícím ve výuce získávaly roli koordinační a řídicí, ve vztahu ke studentům se stávaly „mateřskou“ katedrou. Tyto funkce mají u multidisciplinárního studia mimořádný význam.

Na konci devadesátých let byla po několikaletém útlumu obnovena intenzivní spolupráce mezi pedagogickými fakultami v celostátním měřítku. Jedním z výrazných impulzů $\mathrm{k}$ ní byla mezinárodní konference Univerzitni vzděláváni učiteli primární školy na prelomu století, kterou v roce 1998 u príležitosti 650 . výročí Univerzity Karlovy uspořádala katedra primární pedagogiky Pedagogické fakulty v Praze (Spilková \& Hejlová, 1999). Zúčastnilo se jí více než 70 osobností spjatých se vzděláváním učitelů primárních škol na sedmi českých a pěti slovenských pedagogických fakultách s cílem rekapitulovat, co se na poli vzdělávání této kategorie učitelů odehrálo po roce 1989 v České a Slovenské republice a co lze považovat za pozitivní vývoj, či naopak za vykročení špatným směrem.

Byly reflektovány jak koncepční východiska (proměny paradigmatu primárního vzdělávání, antropogenetického jádra primární pedagogiky, pochopení současného dítěte a dětství, proměny v pojetí učitelské profese, rolí a klíčových kompetencí učitele primární školy apod.), tak konkrétní inovace na jednotlivých českých a slovenských fakultách (změny v obsahu i organizaci studia, proměny v pojetí pedagogických a psychologických disciplín, oborových didaktik, praktické prípravy apod.).

$\mathrm{Na}$ konci devadesátých let byla provedena analýza transformačního úsilí na jednotlivých pedagogických fakultách v ČR. Za nejpodstatnější změny, ke kterým došlo $\mathrm{v}$ průběhu devadesátých let $\mathrm{v}$ celostátním měrítku, byly považovány:

- Posílení profesionalizace studia na většině pedagogických fakult. Pedagogicko-psychologická složka tvoří dominantu, tematickou osu celého studijního programu (20-30\% z celkového objemu studia). Posílena byla také složka osobnostně-kultivační. 
- Celkovou koncepci studia i pojetí nèkterých disciplín ovlivnily principy humanistické pedagogiky, akcentující osobnostně-rozvíjející pojetí primárního vzdělávání.

- Posílení integrativních přístupů, nejčastěji mezi pedagogickými disciplínami - např. namísto dvou samostatných disciplín obecné didaktiky a teorie výchovy integrovaná Školní pedagogika v Brně, či Pedagogika 1. stupně základní školy v Praze, nebo dokonce ještě širší integrace několika pedagogických disciplín pod názvem Primární pedagogika I-V v Ostravě. Dále užší propojení mezi teoretickou a praktickou výukou - v podobě profesních, učitelských praktik $\mathrm{v}$ rámci didaktické výuky, mezi prírodovědnými či společenskovědními obory (např. předmět Integrovaný vědní základ v Brně), mezi oborovými didaktikami (např. Didaktika pro integrovaný vědní základ v Brně je společnou didaktickou př́pravou pro prvouku, vlastivědu a přírodovědu).

- Zkvalitnila se praktická př́prava studentů - ucelený systém praxí s důrazem na reflexi praktických zkušeností a na sebereflexi studenta $v$ roli učitele (s podporou videozáznamu, reflektivního psaní a tvorby portfolia), snahy o hlubší spolupráci s fakultními školami a učiteli.

- Významnou změnou v obsahu studia je také př́íprava studentů na cizojazyčnou výuku v primární škole, nejdříve formou specializace zakončené státní závěrečnou zkouškou, později na některých fakultách povinně pro všechny studenty (např. Olomouc).
- Zařazení nových oborů, disciplín, mezioborových témat $\mathrm{v}$ souvislosti $\mathrm{s}$ potřebami proměňující se školy. Je to zejména masivní vstup dramatické výchovy do studijních programů tohoto oboru (na některých fakultách dokonce formou specializace zakončené státní závěrečnou zkouškou nebo certifikovaným výstupem - např. Ostrava, Praha, Plzeň). Dalšími relativně novými obsahovými prvky jsou např. alternativní pedagogika, inovativní projekty (RWCT, Začít spolu, Zdravá škola, Tvořivá škola), multikulturní výchova, enviromentální výchova, čeština pro cizince, problematika zdraví a zdravého životního stylu.

- Posílení důrazu na speciálněpedagogickou prŕpravu v reakci na integrační tendence v základním školství (míra akcentu je různá, na některých fakultách dokonce jako jedna z možných specializací).

- Výrazné jsou také inovace $\mathrm{v}$ celkovém pojetí, obsahu a metodách výuky některých disciplín. V oblasti pedagogické př́pravy to je zejména pohyb od normativního pojetí pedagogiky $\mathrm{k}$ diskurzivnímu, důraz na činnostní pojetí výuky, uplatňování konstruktivistických príistupů, projektové výuky a kooperativního učení. Zřetelný je důraz na inovace v primárním vzdělávání, zprostředkovávání co nejširšího spektra alternativních podob školy k inspiraci pro vlastní pojetí výuky. $\mathrm{V}$ oblasti oborových didaktik je u některých z nich evidentní snaha o psychodidaktické pojetí. Přes tyto pozitivní změny zůstávají v procesuální stránce výuky, tedy $\mathrm{v}$ pojetí metod 
a strategií výuky, v kvalitě komunikace a sociálního klimatu, na většině fakult ještě velké rezervy.

- Podpora tvůrčí činnost studentů, zapojení do autentické výzkumné práce na fakultě, zahraniční projekty dlouhodobé studentské spolupráce, mezinárodní pedagogické vědecké tábory včetně vydávání mezinárodního studentského sborníku (toto zaměření je výrazné zejména na fakultách v Českých Budějovicích, Hradci Králové, Olomouci a Praze).

- Výrazné snahy o zkvalitnění přijímacího řízení ke studiu s důrazem na posouzení osobnostních předpokladů $\mathrm{k}$ učitelství (Ostrava, Plzeň, Brno) a státních závěrečných zkoušek (formulace problémových okruhů z pedagogiky a psychologie - Brno, obhajování integrovaného projektu jako nástroje k posouzení profesní způsobilosti studenta - Ostrava, využívání portfolia při státních závěrečných zkouškách - Olomouc, Ostrava, experimentální ověřování obhajoby portfolia jako alternativy $\mathrm{k}$ tradičně pojaté státní zkoušce z pedagogiky - Praha).

- Zlepšení institucionálního zajišsění a řízení oboru v kontextu fakult. Posílení kompetencí kateder, ústavů primární pedagogiky jako garanta oboru. Zlepšení součinnosti těchto pracovišt s vedením fakulty. Například vytvoření funkce proděkana pro tento obor - České Budějovice, Hradec Králové, Ústí nad Labem, vedoucí katedry primární pedagogiky je poradcem studijního proděkana - Praha, vznik celofakultního koordinačního orgánu, nap̌r. Oborová rada pro učitelství 1. stupně - Plzeň, zřízení Interní akreditační komise - České Budějovice).
Přes mnoho pozitivních rysů ve vývoji $\mathrm{v}$ průběhu devadesátých let bylo evidentní, že zásadní proměna bude v celostátním měřítku dlouhodobým a náročným procesem. Mnohé inovace jsou teprve v počátečních fázích vývoje (např. psychodidaktické pojetí oborových didaktik, reflektivní pojetí praxe, konstruktivistické prŕstupy $\mathrm{k}$ výuce) a potřebují mimo jiné růst nových osobností vysokoškolských učitelů.

\section{První Desetiletí 21. STOletí}

Po deseti letech nezájmu o učitele a učitelské vzdělávání přináší vzdělávací politika významné impulzy. Je to především Národni program rozvoje vzdéláváni (2001, dále jen Bílá kniha), který zdůrazňuje kvalitu učitelů jako základní podmínku školské reformy. $V$ poprèdí pozornosti jsou žádoucí proměny $\mathrm{v}$ pojetí učitelské profese, rolí a klíčových kompetencí učitele a tomu odpovídající transformace učitelského vzdělávání. $\mathrm{V}$ prŕpadě učitelství pro primární vzdělávání přredstavuje Bílá kniha svou dikcí potvrzení již nastartovaných změn.

Za klíčový princip proměny je $\mathrm{v}$ Bílé knize považována profesionalizace prŕpravy budoucích učitelů. V tomto kontextu je jednou z priorit vzdělávací politiky vytvoření profesních standardů pro jednotlivé kategorie učitelů, které by byly základem pro formulování rámcových programů príipravného vzdělávání učitelů. Profesní standard se měl stát celostátně platným kritériem pro akreditaci vzdělávacích programů $\mathrm{v}$ oblasti učitelského studia.

V návaznosti na Bílou knihu byl zpracován projekt MŠMT Podpora práce učite- 
li̊, jehož hlavním výstupem bylo vytvoření profesních standardů v podobě klíčových kompetencí učitele (Vašutová, 2004). Přestože MŠMT práce na tvorbě profesního standardu zadalo a výsledky verbálně podpořilo, přestože byl návrh diskutován odbornou veřejností a získal podporu, dále se s ním už nepracovalo. Dalším pokusem $\mathrm{v}$ této oblasti bylo zř́zení grémia pro problematiku učitelského studia na vysokých školách, které iniciovalo MŠMT. Výsledkem jeho práce bylo vytvoření minimálních standardů pro učitelskou př́ípravu $\mathrm{v}$ podobě čtyř závazných složek studia a jejich vzájemných proporcí. Stanovení minimální dotace pro pedagogicko-psychologickou složku ve výši $20 \%$ a pro pedagogickou praxi $10 \%$ znamenalo výrazné posílení profesionalizace učitelské př́ípravy. I toto doporučení bylo v intencích již provedených změn ve studiu učitelství pro primární vzdělávání.

Dalším krokem mělo být vymezení klíčových kompetencí učitele jako výstupů prrípravy a definování základního obsahu učitelské př́pravy („nepominutelné obsahy" - předměty, moduly, témata, jež musí studijní program obsahovat). Nakonec se tak nestalo a postupně se začal snižovat i vliv minimálních standardů, až se nakonec z normy závazné pro vysoké školy staly normou pouze doporučenou. Akreditační komise tak ztratila nástroj ke kontrole kvality učitelského vzdělání z hlediska obsahu, $\mathrm{k}$ posouzení, zda studijní programy připravují budoucí učitele na kvalitní a kompetentní výkon učitelské profese $\mathrm{v}$ podmínkách výrazných proměn školy a vzdělávání. To posílilo trend k nežádoucí de-profesio- nalizaci učitelského vzdělávání $\mathrm{v}$ případě učitelství pro 2. stupeň základních škol a škol středních.

Dalším impulzem vzdělávací politiky byl tlak MŠMT na restrukturalizaci studia učitelství v souvislosti s tzv. Boloňskou deklarací (zhruba od roku 2002). Tlak na strukturaci přinesl $\mathrm{v}$ př́padě studia učitelství pro primární vzdělávání výrazné oživení snah degradovat toto studium na bakalářskou úroveň. Začátkem roku 2003 předkládá Pedagogická fakulta MU v Brně (pod nátlakem tehdejšího rektora Zlatušky) jako první v republice žádost o akreditaci strukturovaného studia u všech typů učitelství. Brzy následují fakulty další (např. Plzeň). Politickému tlaku na strukturaci studia odolalo jen učitelství pro primární vzdělávání. Potvrdilo se znovu, jakou sílu má úzká spolupráce vůdčích osobností v oboru primární pedagogika, která vyústila do společného stanoviska fakult opřeného o propracovanou argumentaci (klíčovou roli zde hrály H. Lukášová, V. Spilková, A. Nelešovská). Hlavní argument spočíval $\mathrm{v}$ potřebě integrace vyplývající z širokého profilu a multidisciplinarity studia. Specifické pojetí profesní i oborové př́ípravy vyžaduje integrovaný model studia, který umožňuje průběžnou interakci mezi jednotlivými prvky kurikula v průběhu celého studia a dlouhodobý výcvik některých profesních dovedností (podrobněji in Spilková et al., 2004). Rozhodující bylo, že akreditační komise, resp. pracovní skupina pro pedagogiku, psychologii a kinantropologii (v níž měl zásadní roli J. Mareš) podpořila argumenty o nevhodnosti strukturovaného studia pro tuto kategorii 
učitelů $s$ tím, že by byla příliš radikálním zásahem do již výrazně inovované koncepce jejich př́pravy.

Vliv kontextuálních faktorů na systém prrípravy učitelů byl v uvedeném desetiletí velmi silný. Vzdělávací politika se probudila z nečinnosti, střídaly se pozitivní i negativní aktivity MŠMT. $Z$ těch pozitivních to byl zejména zákon o pedagogických pracovnících z roku 2004, kde je závazně vymezeno magisterské studium jako podmínka pro uznání učitelské kvalifikace (zásadní roli v prosazení tohoto požadavku měl tehdejší poradce ministryně školství J. Kotásek). Dále oživení snah o vytvoření profesního standardu vyjádřené zřízením expertní skupiny pro tvorbu Standardu kvality profese učitele $\mathrm{v}$ roce 2008. MŠMT chápalo standard jako tzv. státní zakázku pro fakulty $\mathrm{z}$ hlediska obsahu prípravy i požadovaného výstupu $\mathrm{v}$ podobě rámcového profilu absolventa. Tato aktivita však nebyla dotažena ze strany MŠMT do konce. $Z$ negativních aktivit vzdělávací politiky uved’me zejména destrukční návrhy novel zákona $(2007,2009)$, které měly umožnit působení stř̌edoškolsky vzdělaných učitelů jako plně kvalifikovaných v základních školách.

Přes řadu nepříznivých vnějších podmínek souvisejících zejména $s$ nekoncepční vzdělávací politikou procházelo učitelství pro primární vzdělávání na pedagogických fakultách dalším pozitivním vývojem. V tomto období úspěšně pokračoval rozvoj oboru primární pedagogika (např. Tomková, 2007; Spilková, 2005; Lukášová, 2003; Lukavská, 2003; Helus, 2004; Kolláriková \& Pupala, 2001; Tomková, Kašová \&
Dvořáková, 2009). K získání jeho prestiže $\mathrm{v}$ rámci pedagogických oborů prrispěly jak teoretické studie, tak empirické výzkumy.

Bylo dosaženo významného pokroku v personálním zajištění oboru - byly jmenovány první tř́i profesorky pedagogiky se zaměřením na primární pedagogiku: H. Lukášová, V. Spilková, A. Nelešovská. Vzniklo solidní zázemí docentů a vedle silné střední generace vyrostla perspektivní generace doktorandů graduovaných $\mathrm{v}$ oboru primární pedagogika. $\mathrm{K}$ tomu přispěl výrazný rozvoj doktorského studia $s$ touto profilací v rámci oboru pedagogika (zejména na fakultách v Olomouci, Praze, Brně) a pro oblast oborových didaktik vznik doktorského studia Teorie primárního př́rodovědného vzdělávání v Ústí nad Labem. Nepodařilo se však spojit odborné zázemí několika fakult do zamýšleného pokusu o konstituování samostatného doktorandského studia v oboru primární pedagogika a vytvoření její celorepublikové oborové rady.

Rozmanitost vývoje na jednotlivých fakultách i měnící se kontext vzdělávací politiky (úvahy o strukturovaném studiu, zavádění pětiletého studia, kreditní systém, pokusy o formulování profesního standardu, požadavky akreditační komise apod.) logicky vyvolaly po jistém útlumu v druhé polovině devadesátých let potřebu obnovit systematickou spolupráci kateder primární pedagogicky v celostátním měŕítku. V prvním desetiletí proběhlo několik významných setkání s celostátním zastoupením v Brně, Českých Budějovicích, Hradci Králové, Olomouci, Ostravě a Praze s cílem jak vzájemného inspirování a sdílení 
zkušeností z praxe vzdělávání učitelů, tak hledání možností spolupráce v oblasti výzkumu i publikační činnosti včetně diskusí o perspektivách dalš́ího vývoje a koordinace strategií směrem ke vzdělávací politice.

$S$ oporou o výstupy z těchto setkání (Spilková \& Hejlová, 2010) lze shrnout, že v tomto desetiletí pokračovaly na všech fakultách významné systémové změny. Studium se prodloužilo na pět let. $\mathrm{Na}$ většině fakult bylo koncipováno i studium v kombinované formě. Některé fakulty (Olomouc, Brno) integrovaly do povinné části kurikula př́pravu studentů na cizojazyčnou výuku namísto dosavadní specializace pro vybranou cást studentů. Obsahové inovace ovlivnil také Rámcový vzdělávací program pro základni vzdèlávání (2005) $s$ nově vymezenými oblastmi vzdělávání a průřezovými tématy. Do studijních programů byly zařazeny tematické oblasti připravující studenty na práci s průřezovými tématy. Většina fakult začlenila do svého kurikula osobnostní a sociální výchovu, multikulturní, environmentální a mediální výchovu; ostatní témata byla integrována jen na některých fakultách, např. Výchova demokratického občana (Praha, Liberec), Výchova k evropanství (Olomouc, České Budějovice).

Pokročila proměna procesů výuky. $\mathrm{V}$ širším měřítku se prosazovaly reflektivní model s prvky klinické praxe a konstruktivistické př́istupy $\mathrm{k}$ budování profesních znalostí, a to především ve výuce pedagogických disciplín, na některých fakultách i v prŕpadě oborových didaktik a psychologie. Dále využití studentského portfolia jako klíčového nástroje profesního rozvoje a jako metody hodnocení a sebehodnocení studenta $\mathrm{v}$ průběhu i závěru studia. Pokročilo se $\mathrm{v}$ prohlubování spolupráce se základními školami a položily se základy mentoringu v učitelství (Plzeň, Praha). Rozšiřovalo se využití projektové metody (Ostrava, Brno). Efektivita inovací byla předmětem výzkumného ověřování $v$ rámci projektů GAČR a výzkumných záměrů MŠMT.

\section{DruHÉ DeSETILETí 21. STOLETí}

Také v tomto období ovlivňují systém prrípravy učitelů vnější faktory. Dlouhodobé podfinancování učitelského studia vyústilo $\mathrm{v}$ polovině uvedeného období do stavu, $\mathrm{v}$ němž je zásadním způsobem ohrožena kvalita studia učitelství. Finanční nouze nastartovala trendy, které jsou v přímém rozporu s pojetím kvalitní př́pravy - tlak na masovost výuky, tedy na nejlevnější formy výuky (přednášky a semináře s velkými počty studentů), omezování výcvikových forem výuky a praxí apod. Honba za projekty a bodovanými publikacemi na úkor kvality výuky, která je mimo kritéria hodnocení vzdělavatelů učitelů. Důležitým kontextuálním faktorem je neschválení profesního standardu a kariérního řádu v roce 2017. A v neposlední řadě novela zákona o pedagogických pracovnících, která již čeká v Poslanecké sněmovně na projednání. Tímto návrhem řeší vzdělávací politika dlouhodobě opomíjený problém nedostatku učitelů absolutní rezignací na kvalitu učitelů, nebot chce otevřít učitelskou profesi všem absolventům vysokých škol. Z hlediska současných nároků 
na profesní kompetence učitelů je to hazardování se vzděláváním mladé generace.

Vývoj na fakultách pokračuje i v těchto v mnohém ohledu nepříznivých podmínkách. Nově vzniklá Fakulta humanitních studií ve Zlíně (2007) nachází postupně své místo mezi fakultami připravujícími učitele - získává akreditaci pro učitelství primárního vzdělávání a pro doktorské studium pedagogiky s výrazným zaměřením na primární a předškolní pedagogiku. Rozvíjí se zde progresivní koncepce studia, která není zatížena tradičními př́stupy.

$\mathrm{Na}$ ostatních pedagogických fakultách v první polovině druhého desetiletí 21. století pokračuje dosavadní vývoj s tím, že jsou dále propracovávány určité oblasti. At́ už jde o specifické profilace a obsahové akcenty, např̀. speciální a inkluzivní pedagogika - Olomouc, Ústí n. L.; psychodidaktika a neurodidaktika - Ústí n. L.; zaměření na umělecké předměty, výchovy - Liberec, Hradec Králové, Praha; inovativně pojaté oborové didaktiky: matematika prof. Hejného - Praha; badatelsky orientovaná výuka $v$ matematice a prírodovědných předmětech - České Budějovice; transdidaktika - Brno; didaktika cizích jazyků - Brno, České Budějovice, Praha; didaktika prrírodovědného vzdělávání - Ústí n. L.; prohloubení integrace pedagogicko-psychologické př́pravy - České Budějovice. V souvislosti se zánikem Akreditační komise vlády ČR v roce 2016 a vznikem Národního akreditačního úřadu využily některé fakulty proces nových akreditací $\mathrm{k}$ dalším koncepčním proměnám.

Současně $s$ těmito pozitivními trendy se objevují také rizika a diskutabil- ní tendence. Objevuje se tlak na stírání specifik tohoto učitelského oboru a jeho přiblížení koncepci studia učitelství pro sekundární školy (Praha). V posledních letech proběhlo personální „tsunami“ ve vedení kateder primární pedagogiky na třech pedagogických fakultách, které byly po dlouhou dobu lídry rozvoje oboru (Olomouc, Ostrava a Praha). Z těchto pracovišt odešly z vlastního rozhodnutí tři profesorky oboru (v Praze kromě toho $\mathrm{v}$ posledním roce ještě dva docenti, také vůdčí osobnosti v dané oblasti). Ve všech třech uvedených př́padech došlo poté $\mathrm{k}$ více či méně výrazné diskontinuitě vývoje, zpochybňování dosavadní koncepce studijního oboru a snahám o její změnu. Obecněji řečeno jde o střet paradigmat - akademické pojetí př́pravy učitelů versus profesionalizační pojetí s důrazem na reflektivní praxi a na rozvoj profesních kompetencí učitele, které jsou klíčové pro kvalitní zvládání profese. Zásadní paradigmatickou otázkou je také střet pojetí primárního vzdělávání - dosud dominantní antropocentrické, na dítě orientované pojetí versus materiocentrický, tzv. obsahově zaměřený prístup. Čas ukáže, zda půjde pouze o dočasnou a částečnou snahu o vychýlení z dosavadního směrování, nebo se bude jednat o trend obecnější.

Závěrem lze shrnout, že vzdělávání této kategorie učitelů prošlo $\mathrm{v}$ uplynulých téměr třiceti letech na všech pedagogických fakultách proměnou celkové koncepce studia. Jednalo se o změny zásadní a dá se říct, že se prosadilo v základních rysech nové 
pojetí učitelského vzdělávání $s$ důrazem na profesionalizaci, což vynikne zejména při srovnání se situací v učitelství pro vyšší školské stupně.

Přes do značné míry neprýiznivé vnější podmínky, mezi nimiž dominovaly nekoncepční vzdělávací politika vytvářející spíš překážky než potřebnou podporu, dále postavení pedagogických fakult $\mathrm{v}$ rámci některých univerzit a také postavení oboru $\mathrm{v}$ rámci některých fakult, lze konstatovat, že cesta proměny byla $\mathrm{v}$ zásadě úspěšná. Studium v aktuální podobě připravuje studenty na nároky současné praxe, na osobnostně rozvojové pojetí primárního vzdělávání. Svou celkovou koncepcí, obsahem i způsoby výuky je ve shodě $s$ klíčovými mezinárodními trendy.

Zásadní roli $\mathrm{v}$ úspěšné transformaci studijního oboru měla dlouhodobá úzká spolupráce mezi fakultami, respektive prríslušnými katedrami, $\mathrm{v}$ koncipování a reflexi proměn studia, ve výzkumu, v mezinárodních projektech apod. Tento fenomén lze považovat za důležitou hodnotu oboru primární pedagogika a učitelství pro primární školu, za „rodinné stříbro“, o které je třeba systematicky pečovat. $\mathrm{V}$ tomto smyslu je výzvou pro mladší generaci přebrat štafetu od zakladatelů oboru, podporovat kontinuitu $\mathrm{v}$ kvalitě oboru a odpovědně usilovat o jeho další rozvoj.

\section{Literatura}

Helus, Z. (1991). Dítě jako východisko školské reformy. Výchova a vzdělání, 1(6), 117-120. Helus, Z. (2004). Ditě v osobnostním pojetí. Praha: Portál.

Kolláriková, Z., \& Pupala, B. (2001). Předškolni a primárni pedagogika. Praha: Portál. Kurzweil, J., Mikulec, J., \& Vinš, V. (1995). Akreditace pedagogických fakult. Alma mater, 5(5-6), 256-263.

Lukášová, H. (2003). Učitelská profese v primárním vzděláváni a pedagogická príprava učitelì (teorie, výzkum, praxe). Ostrava: Pedagogická fakulta OU.

Lukavská, E. (2003). Pozor, děti! Dobrá Voda: Aleš Čeněk.

Mareš, J., \& Beran, J. (1995). Akreditace kateder psychologie a kateder pedagogiky. Alma mater, 5(5-6), 277.

Ries, L., Kantorková, H. et al. (1994). Alternativní vysokoškolská príprava učitele obecné školy. Rozvojový projekt Fondu rozvoje vysokých škol (rukopis).

Spilková, V. (1991). Obecná východiska koncepce studia učitelství pro 1. stupeň základní školy. Pedagogika, 41(4), 477-483.

Spilková, V. (1994). Alternativní model přípravy učitelů 1. stupně základní školy. In Stát se učitelem. Výzkumná zpráva (s. 199-222). Praha: Pedagogická fakulta UK.

Spilková, V. (1997). Promény primární školy a vzděláváni učitelù v historicko-srovnávaci perspektivè. Praha: Pedagogická fakulta UK.

Spilková, V. (2005). Proměny primárního vzděláváni v ČR. Praha: Portál.

Spilková, V. (2016). Př́istupy české vzdělávací politiky po roce 1989: Deprofesionalizace učitelství a učitelského vzdělávání? Pedagogika, 66(4), 368-385. 
Spilková, V. (2019). Reflexe proměn vzdělávání učitelů pro primární vzdělávání v České republice po roce 1989. In Z. Pechová, Z. Prokeš et al., Prostor pro primárni a preprimárni pedagogy (s. 158-162). Liberec: TUL.

Spilková, V. et al. (2004). Současné promény vzděláváni učitelů. Brno: Paido.

Spilková, V., \& Hejlová, H. (Eds.). (1999). Univerzitni vzdèláváni učiteli primárni školy na prelomu století. Praha: Pedagogická fakulta UK.

Spilková, V., \& Hejlová, H. (Eds.). (2010). Připrava učiteli̊ pro primárni a preprimárni vzdèláváni v Česku a na Slovensku. Vývoj po roce 1989 a perspektivy. Praha: Pedagogická fakulta UK. Štech, S. et al. (1995). Psychodidaktický sešit. Praha: Pedagogická fakulta UK.

Tomková, A. (2007). Program Čtením a psanim ke kritickému myšlení v primárni škole. Praha: Pedagogická fakulta UK.

Tomková, A., Kašová, J., \& Dvořáková, M. (2009). Učime v projektech. Praha: Portál.

Urbánek, P. (2013). Vzdělávání učitelů v České republice (po Česku): Riziko deprofesionalizace. In J. Ferencová \& I. Ištván (Eds.), Križovatky na cestách k učitelstvu. Prešov: FHPV PU a Škola plus.

Vašutová, J. (2004). Profese učitele v českém vzdělávacím kontextu. Brno: Paido.

prof. PhDr. Vladimira Spilková, CSc.

Univerzita Pardubice, Filozofická fakulta, katedra anglistiky a amerikanistiky;

e-mail:vladimira.spilkova@upce.cz 